Taşkın, Y. ve Karakuş Tayşi, E. (2018). Proje tabanlı öğrenme yaklaşımının yazma becerisine ve yazma kaygısına etkisi. Ana Dili Eğitimi Dergisi, 6(4), 1226-1240.

$\begin{gathered}\text { Ana Dili Eğitimi Dergisi } \\ \text { Journal of Mother Tongue Education } \\ \text { www.anadiliegitimi.com }\end{gathered}$
Geliş/Received: 16.09 .2018 Kabul/Accepted:05.10.2018

\title{
Proje Tabanlı Öğrenme Yaklaşımının Yazma Becerisine ve Yazma Kaygısına Etkisi *
}

\author{
Yusuf TAŞKIN ** \\ Esra KARAKUŞ TAYŞi***
}

\begin{abstract}
Öz
Bu çalışmanın amacı, Proje Tabanlı Öğrenme Yaklaşımııı (PTÖY) ortaokul öğrencilerinin yazma becerilerine ve yazma kaygılarına etkisini araştırmaktır. Çalışmanın yöntemi ön test-son test kontrol gruplu yarı deneysel desendir. Araştırma, istanbul ili Kağıthane ilçesinde bulunan Cengizhan Ortaokulunda 2016-2017 eğitim-öğretim yilında 7. sınıfta öğrenim gören 100 öğrenci üzerinde yürütülmüştür. Deney gruplarında PTÖY'nin aşamaları takip edilirken kontrol gruplarında mevcut Türkçe Dersi Öğretim Programı́nın aşamaları takip edilmiştir. Deneysel çalışma 10 hafta sürmüştür. Verilerin toplanmasında araştırmacılar tarafından geliştirilen Yazııı Anlatım Becerisi Dereceli Puanlama Anahtarı, Yazma Kaygısı Ölçeği, Kişisel Bilgi Formu ve Proje Değerlendirme Ölçeği kullanılmışır. Araştırma sonucunda, öğrencilerin yazılı anlatım becerisi başarı puanlarının deney grupları lehine anlamlı ve daha yüksek olduğu tespit edilmiştir. Ayrıca deney ve kontrol gruplarındaki öğrencilerinin yazma kaygısı puanlarının deney grupları lehine istatistiksel olarak anlamlı düzeyde değiştiği sonucuna ulaşılmıştır. Bu sonuçlara göre Türkçe derslerinde PTÖY'nin uygulanmasının, öğrencilerin yazma becerisini geliştirmede ve yazma kaygılarının giderilmesinde etkili olduğu söylenebilir.
\end{abstract}

Anahtar Kelimeler: Yazma becerisi, yazma kaygısı, yazma eğitimi, proje tabanlı öğrenme yaklaşımı, ortaokul.

\section{The Effect of Project Based Learning Approach on Writing Skills and Writing Anxiety}

\begin{abstract}
The aim of this study is to figure out the effects of Project Based Learning Approach (PBLA) on writing skills and writing anxiety of middle school students. Method of the study is quasiexperimental design with pre-test post-test control groups. The research was carried out among 100 students who study in the $7^{\text {th }}$ grade in 2016-2017 education year in Cengizhan Middle School which is in Kağtthane region of İstanbul province. While PBL stages were followed in the experimental group, stages of current Turkish Lesson Curriculum were followed in the control group. The experimental study lasted 10 weeks. For the data collection, Written Expression Skills Graduate Grading Key, Writing Anxiety Scale, Personal Information Form, and Project Evaluation Scale prepared by the researchers were used. Results of this research showed that success points of written expression skills of students were significant and higher in experimental groups' favour. In addition, it was concluded that writing anxiety points of students in experimental and
\end{abstract}

\footnotetext{
*Bu çalışma, Dr. Öğr. Üyesi Esra KARAKUŞ TAYŞi danışmanlığında Yusuf TAŞKIN tarafından hazırlanan "Proje Tabanlı Öğrenme Yaklaşımının Yazma Becerisine ve Yazma Kaygısına Etkisi" isimli yüksek lisans tezinden üretilmiştir.

${ }^{* *}$ Doktora öğrencisi, Yıldız Teknik Üniversitesi, Sosyal Bilimler Enstitüsü, Türkçe ve Sosyal Bilimler Eğitimi ABD, Türkçe Eğitimi Bilim Dalı, İstanbul, y_taskin43@hotmail.com

${ }^{* * *}$ Dr. Öğr. Üyesi, Dumlupınar Üniversitesi, Eğitim Fakültesi, Türkçe ve Sosyal Bilimler Eğitimi Bölümü, Kütahya, esra.karakus@dpu.edu.tr
} 
control groups differed on a statistically significant level in experimental groups' favour. According to these results, it can be stated that implementation of PBL in Turkish lessons is effective for the improvement of students' writing skills and in the elimination of their writing anxiety.

Keywords: Writing skill, writing anxiety, writing education, project-based learning approach, middle school.

\section{Giriş}

Yazma becerisi ile düşünme arasında sıkı bir bağ vardır. Yazılı bir ürün aynı zamanda düşüncenin ürünüdür. Düşünce, bilgi birikim gerektiren, kendi içinde zihinsel paradigmaları olan karmaşık bir süreçtir. Yazma becerisinde diğer becerilerde olduğu gibi hata yapıldığında tekrar etme ya da anında düzeltme pek fazla olmaz. Yazma becerisinde oluşturulan yazılı ürünün yazardan çıktıktan sonra geriye dönüp düzeltilme çok azdır. Ayrıca yazma becerisinde içerik kadar buluş, düzen, seçim, bellekte tutma ve sunuş da o derece önemlidir. Yani yazma becerisini kazanabilmek için hayatın çoğu evresinde olduğu gibi disiplin, plan ve düzen mutlaka gerekir (İşeri ve Ünal, 2012). Yazma becerisi ağır ve yavaş gelişim göstermesi, diğer becerilerin gelişimine paralel olması zor bir beceri olduğunu göstermektedir. Bu bağlamda yazma becerisinin eğitiminde de bazı zorluklar ortaya çıkmaktadır. Özellikle yazma eğitiminin en yoğun verildiği Türkçe derslerinde iyi bir planlama yapılmadan uygulanan yazma etkinlikleri öğrencilerin yazmaya karşı olumsuz tutum geliştirmelerine ve yazmayı zor bir beceri olarak algılamalarına sebep olmaktadır (Maltepe, 2007). Yazma becerisinin tek başına teorik ve teknik bilgi ile kazanılması zor olduğundan bilginin içselleştirilmesi ve uygulamaya dökülmesi gerekmektedir. Yazma eğitim sürecini planlarken ve süreci uygularken bunlara dikkat edilmeli, gerekli eğitim ortamları oluşturulmalı ve eğitim süreci bütüncül olarak ele alınmalıdır.

Yazma becerisinin belli bir birikim gerektirmesi, zaman içinde gelişmesi, her zaman ilgi ve motivasyonun yüksek tutulmasının zorluklarından kaynaklı öğrencinin zihninde oluşan yazmaya yönelik kaygıların ortadan kaldırılması gerekir (Ateş, Yıldız ve Ercan, 2016). Kaygı, aşırı düzeyde olmadıktan sonra bireye düşüncelerini seçmede, sıralamada, düzenlemede ve yazıya aktarmada yardımcı olur. Bu sayede birey, kendini daha iyi ifade edebilir (Aşılıŏlu ve Özkan, 2013). Yazma kaygısı; zorunlu olarak yazma etkinliğine maruz kalan bireyin korkmalarına, çekinmelerine, yazmaya başlayamamalarına (ertelemelerine) ya da başlanan bir yazma etkinliğini tamamlayamamalarına neden olur. Farklı alanlarda karşılaşıldığı gibi yazma etkinlikleri esnasında da kaygı, bireyi olumsuz yönde etkilemektedir (Katrancı, 2015). Yazma kaygısı, her bireyin kendi hayatındaki yaşanmışlığına istinaden ortaya çıkan bir durumdur.

Yazma kaygısının yüksek veya düşük olduğu durumlarda öğrencilerin yazmaya yönelik tepkilerinin nasıl olduğunun belirlenmesine yönelik birçok araştırmacı tarafından farklı zamanlarda farklı öğrenci gruplarına yönelik çalışmalar yapılmıştır (Aşılıŏlu ve Özkan, 2013; Ateş, Yıldız ve Ercan, 2016; Bloom, 1980; İşeri ve Ünal, 2012; Karakaya ve Ülper, 2011; Katrancı, 2015). Ayrıca yazma 
Proje Tabanlı Öğrenme Yaklaşımının Yazma Becerisine ve Yazma Kaygısına Etkisi

kaygısı düşük olan öğrenciler ile yüksek olan öğrenciler arasındaki farkların bilinmesi ve eğitim öğretim sürecinde dikkate alınması gerekir. Yazma kaygısı yüksek olan öğrencilerin yazmaktan kaçındıkları, düşük olan öğrencilerin yazı yazmaya istekli oldukları anlaşılmaktadır. Yazmaya karşı kaygı duyulmalı ancak kaygı düzeyinin gereğinden az veya fazla olmamasına dikkat edilmelidir. Yazma sürecinde öğrencilerin oluşturdukları yazılı ürünlerin olumlu taraflarını pekiştirerek onları yazmaya yönelik cesaretlendirmek gerekir. Buna benzer olumlu davranışların pekiştirilmesi öğrencinin yazmaya yönelik var olan korkusunu azaltacağı gibi kaygı düzeyini de istendik seviyelere düşürecektir. Böylelikle öğrenciler yazmaya yönelik daha istekli hâle gelecektir.

Öğrencilerin yazma kaygısını ortadan kaldırmak için farklı yöntemler izlenebilir. Eğitim alanındaki yeniliklerden hareketle ortaya çıkan çağdaş öğretim yaklaşımları bu yöntemlere kaynaklık etmektedir. Çağdaş yaklaşımlarda, geleneksel yaklaşımda olduğu gibi bireyin bilgiyi bir öğretici tarafından anlatılarak edinmesinden ziyade bilgiye kendisinin ulaşması hedeflenir. İşte geleneksel yaklaşımların aksine öğretmen merkezli anlayış yerine öğrenen merkezli modern yöntemler, öğrenciyi eleştirel düşünmeye, sorgulamaya, bilgi ve buluşlarını ispatlamaya, bireysel fikirler oluşturmaya, problem çözmeye ve kendi fikirlerini korkusuzca ifade etmeye yönlendirir (Demiral, 2015). Eğitim öğretimin öğrenen merkezli olmasını savunan, öğrenmeyi daha işlevsel hale getiren çağdaş öğrenme yaklaşımlarından biri de Proje Tabanlı Öğrenme Yaklaşımı (PTÖY)'dır.

PTÖY, bireysel ya da küçük gruplar aracılığıyla hayatın içinden alınan problem senaryoları üzerine kurulan gerçek durumları öğrenim ortamına taşıyan ve öğrenciyi eğitim öğretim sürecinin merkezine alan disiplinler arası çağdaş öğrenme yaklaşımlarından biridir (Ayvacı ve Çoruhlu, 2010; Demiral, 2015). Projelerin temel amacı öğrencilere bir kavramı ya da beceriyi kazandırmak, öğrenme sürecinde sorumluluk sahibi olmasını sağlamak, başkalarıyla iş birliği içinde çalışma alışkanlığı edindirmektir. PTÖY'de öğretmen öğrenci ilişkisi geleneksel yaklaşımlardan biraz farklıdır. Öğretmen öğrencilerine bireysel öğrenme becerilerini kazandırmanın yanı sıra grup olarak çalışabilmeyi, öğrenmeye karşı istekli olabilmeyi, zorluklar ve engeller karşısında cesaretli olabilmeyi, farklı başarılara ulaşmalarını sağlayarak motivasyonunu artırabilmeyi, sorumluluk almayı ve üst düzey bilişsel beceri kazandırmayı hedefler.

PTÖY aşamalarını beş başlık altında toplanmıştır. Bunlar planlama ve giriş, geliştirme ve zenginleştirme, yürütme(uygulama), sunum, rapor ve değerlendirme aşamalarıdır. PTÖY'nin tam ve eksiksiz olarak uygulanabilmesi için uygulayıcıların bu aşamalara dikkat etmesi gerekir.

PTÖY'nin diğer öğrenme yaklaşımlarına göre üstün taraflarını, öğrenciye yaparak yaşayarak öğrenebilme, bağımsız çalışabilme, işbirliği ve dayanışma yapabilme, tek kaynağa bağlı kalmadan farklı kaynakları kullanabilme, planlı çalışabilme, farklı öğrenme ortamları deneyimleyebilme, eleştirel düşünme, sorgulama, problem çözme, yaratma gibi üst düzey zihinsel becerileri kullanabilme; 
PTÖY'nin sınırlııklarını ise, hedeflenen süreden sapma, öğretmenin bilgi ve becerisindeki yetersizlikten kaynaklı aksaklıklar, sınıf yönetiminin zorlaşması, proje için gerekli materyallerin maliyeti, bazı öğrencilerin kendini yetersiz görmesi, projelerin farklı kişilerce yapılması, denetimin zorlaşması şeklinde sıralanabilir (Acar, 2011; Çiftçi, 2006; Demiral, 2015; Korkmaz ve Kaptan, 2001; Saraçoğlu, Özyılmaz Akmaca ve Yeşildere, 2006). PTÖY'nin eğitim öğretimde verimli olarak kullanılması için bu üstün yanların ve sınırlııkların çok iyi bilinmesi gerekir. Eğitim öğretim sürecinde PTÖY öğretmenin bilgiyi aktaran, öğrenenin ise bilgiyi alan anlayışı yerine, araştırmaya, sorgulamaya, eleştirmeye, problem çözmeye, yaratmaya dayalı, öğrencinin süreçte aktif rol oynadığı, gerçek hayatla iç içe bir öğrenme ortamı sunar. PTÖY'de en temel amaçlardan biri bilginin kullanılması yani beceriye dönüştürülmesidir. Hedeflenen bu becerilerin ne kadarının kazanıldığı ne kadarın kazanılmadığının belirlenebilmesi için ölçme değerlendirme çalışmalarına başvurulmaktadır. PTÖY’de süreç ve ürün odaklı olmak üzere üç değerlendirme yöntemine yer verilmiştir. Bunlar "proje değerlendirme rubrikleri, proje portfolyoları ve proje günlüğü" yöntemidir. PTÖY'de kullanılan bu yöntemler sayesinde geleneksel yöntemlerden farklı olarak öğrencilerin bilgilerinin yanında becerilerinin de ölçülmesine imkân sağlanmıştır. PTÖY sayesinde öğrencilerin; yazma becerisine yönelik akademik başarııının artırılması, tespit edilen yazma sorunlarının giderilmesi, kendilerini özgür hissedeceği yazma projeleri geliştirmeleri sayesinde var olan yazma kaygılarının ortadan kaldırılması kolaylaşacaktır. Bu nedenlerle araştırmanın amacı, PTÖY'nin ortaokul öğrencilerinin yazma becerilerinin geliştirilmesine ve yazma kaygılarının giderilmesine olan etkisini tespit etmektir.

\section{Yöntem}

\section{Araştırmanın Modeli}

Bu araştırmada, PTÖY'nin öğrencilerin yazma becerisi üzerindeki etkisi sınanmıştır. Farklı bir ifadeyle bağımsız değişkenin (PTÖY) bağımlı değişken (ortaokul 7. sınıf öğrencilerin yazma becerisi) üzerinde etkili olup olmadığı araştırılmıştır. Bu bağlamda değişkenler arasındaki nedensellik ilişkisini tespit etmek için planlanmış etkinlik ve projeler içeren nicel araştırma yöntemlerinden ön test-son test kontrol gruplu yarı deneysel desen kullanılmıştır. Yarı deneysel desende kendiliğinden oluşan deney grupları sayesinde karşılaştırma yapılabilir. Doğal yollarla oluşan deney grupları, araştırma amaçları doğrultusunda kurgulanmamış olsalar bile az çok tanımlıdırlar. Bu sebeple deneyin araştırmacı tarafından denetlenmesi çok zordur. Ancak araştırmacı, bağımsız değişkenin sonuç değişkenleri üzerindeki etki düzeyini ölçerken belli ölçüde denetleme olanağı bulur (Büyüköztürk, 2014; Creswell, 2017; Punch, 2014).Araştırma sürecinde kullanılan ön test-son test yarı deneysel modelin simgesel görünümü ise Tablo $1^{\prime}$ de gösterilmiştir. 
Proje Tabanlı Öğrenme Yaklaşımının Yazma Becerisine ve Yazma Kaygısına Etkisi

Tablo 1. Araştırmada kullanılan yarı deneysel modelin simgesel görünümü

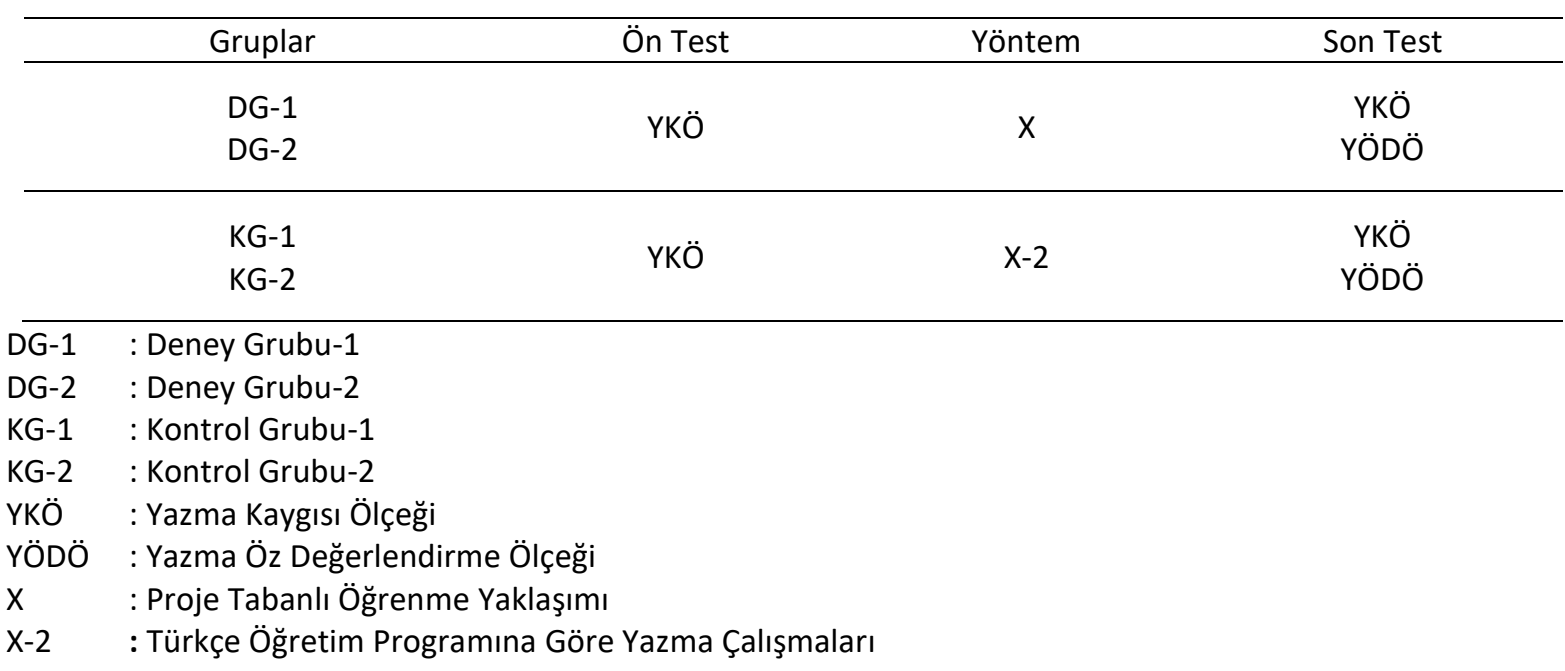

\section{Çalışma Grubu}

Araştırmanın çalışma grubunu 2016-2017 eğitim öğretim yılında İstanbul ili Kağıthane ilçesindeki Milli Eğitim Bakanlığına bağlı Cengizhan Ortaokulunda öğrenim görmekte olan 100 yedinci sınıf öğrencisi oluşturmaktadır. Yedinci sınıf öğrencileri yaş, hazırbulunuşluk, akademik kaygı bakımından uygun olduğu için tercih edilmiştir. Araştırmaya karar verilen okul ve araştırmaya katılan öğrenciler gönüllülük esasına göre belirlenmiştir. Araştırma için İstanbul Valiliği ve il Milli Eğitim Müdürlüğünden gerekli resmi izin alınmıştır. Araştırmada yarı deneysel desen kullanılması sebebiyle evren ve örneklem yerine çalışma grupları belirlenmiştir. Çalışmada okulda bulunan yedinci sınıf şubelerinden dördü, sınıf mevcutları, cinsiyet dağılımı, Türkçe ders notları ve akademik başarıları bakımından karşılaştırılmıştır.

\section{Veri Toplama Araçları}

Araştırmada veri toplama aracı olarak öğrencilere ait bilgileri tespit etmek amacıyla araştırmacılar tarafından geliştirilen "Kişisel Bilgi Formu", "Yazma Kaygısı Ölçeği (YKÖ)", "Yazılı Anlatım Becerisi Dereceli Puanlama Anahtarı (YABDPA)" "Proje Değerlendirme Ölçeği (PDÖ)" kullanılmıştır. YKÖ’nin geçerlik ve güvenirlik çalışmaları sonucunda KMO değeri ,838; Bartlett's Küresellik Testi değeri $\chi 2=1767,902 ;$ sd=171 p<. ,000; iç tutarlılığının hesaplanmasında kullanılan Cronbach's Alpha güvenirlik kat sayısı ,790 olarak hesaplanmıştır. Faktör analizi sonucunda ölçeğin toplam varyansının \% 41,036'sını açıklayan ve üç faktör altında toplanan 16 maddelik bir ölçeğe ulaşılmıştır. Araştırma bulgularına dayanarak ölçeğin geçerli ve güvenilir olduğu söylenebilir (Karakuş Tayşi ve Taşkın, 2018). YABDPA ise 5 alan uzmanı ve 8 Türkçe öğretmeninin görüşleri doğrultusunda "Biçim, Dil ve Anlatım, Yazım ve Noktalama" olmak üzere üç boyutlu 18 maddelik geçerli ve güvenilir bir ölçek elde edilmiştir. PDÖ, yapılan literatür taraması ve üç alan uzmanın görüşü sonucunda öğrencilerden yazması beklenen hikâye, deneme, anı, söyleşi, tiyatro ve röportaj türlerini değerlendirebileceği düşünülen 5'li Likert tipi ölçek formunda hazırlanmıştır. 


\section{Uygulama Süreci}

Araştırmanın işlem sürecinde öğrencilerin yazma becerileri ve kaygıları ile ilgili hedeflenen kazanımlara ulaşacak şekilde PTÖY'nin ilkeleri doğrultusunda 8 haftalık bir çalışma planı hazırlanmıştır. Bu süreç oluşturulurken şu aşamalar takip edilmiştir:

1. Her hafta yapılacak olan çalışmalar, PTÖY'nin ilkeleri dikkate alınarak hazırlanmış, kazandırılması gereken hedef ve davranışlar buna göre düzenlenmiştir.

2. İstanbul İ Milli Eğitim Müdürlüğünden ve Cengizhan Ortaokulu Müdürlüğünden gerekli izinler alındıktan sonra okul idarecileri ve öğrenciler PTÖY hakkında detaylı bir şekilde bilgilendirilmiştir. Bu süreçte okul idarecilerinin ve öğrencilerin akıllarına takılan sorular cevaplanmıştır.

3. Belirlenen deney grupları öğrencilerine araştırma aşamasında yapılacaklar detaylı bir şekilde anlatılmış ve öğrencilere süreçle ilgili Powerpoint sunumu yapılmıştır. Öğrencilere, bu araştırma boyunca hangi aşamalardan geçecekleri, nasıl araştırma yapacakları, verilere nasıl ulaşacakları, elde ettikleri verileri nasıl analiz edecekleri, nasıl sunum yapacakları ve nasıl bir değerlendirme sürecinden geçecekleri hakkında detaylı bilgi verilmiştir.

\section{Verilerin Analizi}

Araştırmada elde edilen veriler bilgisayar ortamına aktarıldıktan sonra değişkenlerin dağılımının normallik gösterip göstermediğine bakılmıştır. Büyüköztürk (2016) ve Özer (2007) grup büyüklüğünün 50 'den küçük olduğu durumlarda Shapiro-Wilk, büyük olduğu durumlarda ise Kolmogorov-Smirnov testlerinin veri dağılımının normalliğini belirleyebilmek için kullanılabileceğini belirtmiştir. Ayrıca parametrik testlerde ön şart olarak kabul edilen varyansların homojenliği "Levene" testiyle kontrol edilmiştir. Herhangi bir ön şartı sağlamayan parametre için Box-Cox veri transformasyonu uygulaması sonucunda elde edilen bilgiler tekrar kontrol edildiğinde değerlerin ön şartları sağladıkları görülmüştür. Tüm bu dağılımlar Shapiro-Wilk testi ile kontrol edilmiş ve yapılan analizler sonucunda verilerin normal dağılım gösterdikleri görülmüştür. Bu nedenle analizlerde t-testi ve ANOVA testinden yararlanılmıştır. Araştırmadaki istatistiksel analizlerde anlamlı farklılık için 0.05 düzeyi dikkate alınmıştır.

\section{Bulgular}

Deney ve Kontrol Gruplarındaki Öğrencilerin Yazıı Anlatım Becerileri Ön Test ve Son Test Puanlarına ilişkin Bulgular

Araştırmaya katılan deney ve kontrol gruplarındaki öğrencilerin uygulama yapılmadan önce ve yapıldıktan sonra yazdıkları metinler YABDPA ile değerlendirilmiştir. Bu değerlendirmeden elde edilen öğrenci puanları arasında istatistiksel olarak anlamlı bir farkın olup olmadığına bakılmıştır. 
Proje Tabanlı Öğrenme Yaklaşımının Yazma Becerisine ve Yazma Kaygısına Etkisi

Deney ve kontrol gruplarındaki öğrencilerin (Deney-1, Deney-2 ve Kontrol-1, Kontrol-2) aldıkları bu puanlar arasında istatistiksel olarak anlamlı fark olup olmadığının belirlenebilmesi için t-testi ve tek yönlü varyans analizi (ANOVA) yapılmıştır.

Tablo 2. Deney-1 Grubunun Yazılı Anlatım Becerileri Ön Test ve Son Test Puanlarına ilişskin T-Testi Sonuçları

\begin{tabular}{ccccccc}
\hline Ölçüm (YABDPA) & $\mathrm{N}$ & $\mathrm{X}$ & $\mathrm{S}$ & $\mathrm{sd}$ & $\mathrm{t}$ & $\mathrm{p}$ \\
\hline Ön test & 24 & 72.20 & 11.06 & 23 & -4.31 & .000 \\
Son test & 24 & 78.87 & 8.85 & & & \\
\hline
\end{tabular}

Tablo 2'deki Deney-1 grubuna ( $\mathrm{N}=24)$ ait analiz sonuçları incelendiğinde ön test ve son test puanları arasında istatistiksel olarak anlamlı bir fark [t(23)=-4.31; $\mathrm{p}<.05]$ olduğu görülmektedir. Deney-1 grubundaki öğrencilerin uygulama öncesi aldıkları puanların ortalaması $(X=72.20, S=11.06)$ iken, PTÖY uygulamaları sonrasında ( $\mathrm{X}=78.87, \mathrm{~S}=8.85$ ) olarak hesaplanmıştır.

Tablo 3. Deney-2 Grubunun Yazılı Anlatım Becerileri Ön Test ve Son Test Puanlarına Iliş̧kin T-Testi Sonuçları

\begin{tabular}{ccccccc}
\hline Ölçüm (YABDPA) & $\mathrm{N}$ & $\mathrm{X}$ & $\mathrm{S}$ & $\mathrm{sd}$ & $\mathrm{t}$ & $\mathrm{p}$ \\
\hline Ön test & 26 & 72.92 & 11.22 & 25 & -5.03 & .000 \\
Son test & 26 & 78.50 & 12.10 & & &
\end{tabular}

Tablo 3'teki Deney-2 grubuna ( $N=26)$ ait analiz sonuçları incelendiğinde ön test ve son test puanları arasında istatistiksel olarak anlamlı bir fark [t(25)=-5.03; $\mathrm{p}<.05]$ olduğu görülmektedir. Deney-2 grubundaki öğrencilerin uygulama öncesi aldıkları puanların ortalaması ( $X=72.92, S=11.22$ ) iken, PTÖY uygulamaları sonrasında ( $X=78.50, S=12.10)$ olarak hesaplanmıştır.

Deney-1 ve Deney-2 gruplarındaki öğrencilerden elde edilen veriler üzerinde yapılan analizler sonucundaki bulgulara göre PTÖY uygulamasının öğrencilerin yazılı anlatım becerisi başarılarını artırmada önemli bir etkiye sahip olduğu söylenebilir.

Tablo 4. Kontrol-1 Grubunun Yazılı Anlatım Becerileri Ön Test ve Son Test Puanlarına Ilişkin T-Testi Sonuçları

\begin{tabular}{ccccccc}
\hline Ölçüm (YABDPA) & $\mathrm{N}$ & $\mathrm{X}$ & $\mathrm{S}$ & $\mathrm{sd}$ & $\mathrm{t}$ & $\mathrm{p}$ \\
\hline Ön test & 24 & 72.29 & 10.44 & 23 & 1.81 & .083 \\
Son test & 24 & 70.04 & 11.40 & & &
\end{tabular}

Tablo 4'teki Kontrol-1 grubuna ( $\mathrm{N}=24)$ ait analiz sonuçları incelendiğinde ön test ve son test puanları arasında istatistiksel olarak anlamlı bir fark $[\mathrm{t}(23)=1.81 ; \mathrm{p}>.05]$ olmadığı görülmektedir. Kontrol-1 grubundaki öğrencilerin uygulama öncesi aldıkları puanların ortalaması $(X=72.29, S=10.44)$ iken, mevcut TDÖP uygulamaları sonrasında ( $X=70.04, S=11.40)$ olarak hesaplanmıştır.

Tablo 5. Kontrol-2 Grubunun Yazılı Anlatım Becerileri Ön Test ve Son Test Puanlarına Iliş̧kin T-Testi Sonuçları

\begin{tabular}{ccccccc}
\hline Ölçüm (YABDPA) & $\mathrm{N}$ & $\mathrm{X}$ & $\mathrm{S}$ & $\mathrm{sd}$ & $\mathrm{t}$ & $\mathrm{p}$ \\
\hline Ön test & 26 & 71.76 & 12.24 & 25 & 1.80 & .083 \\
Son test & 26 & 69.60 & 12.36 & & & \\
\hline
\end{tabular}


Tablo 5'teki Kontrol-2 grubuna ( $N=26)$ ait analiz sonuçları incelendiğinde ön test ve son test puanlarının istatistiksel olarak anlamlı bir fark $[t(25)=1.81 ; p>.05]$ göstermediği görülmektedir. Kontrol-2 grubundaki öğrencilerin uygulama öncesi aldıkları puanların ortalaması $(X=71.76, S=12.24$ ) iken, mevcut TDÖP uygulamaları sonrasında $(X=69.60, S=12.36)$ olarak hesaplanmıştır.

Tablo 6. Yazııı Anlatım Becerisi Dereceli Puanlama Anahtarı Ortalama Puan ve Standart Sapma Sonuçları

\begin{tabular}{ccccccc}
\hline \multirow{2}{*}{ Grup } & \multicolumn{3}{c}{ Ön Test } & \multicolumn{3}{c}{ Son Test } \\
\cline { 2 - 7 } & $\mathrm{N}$ & $\mathrm{X}$ & $\mathrm{S}$ & $\mathrm{N}$ & $\mathrm{X}$ & $\mathrm{S}$ \\
\hline Deney & 50 & 72.58 & 11.03 & 50 & 78.68 & 10.56 \\
\hline Kontrol & 50 & 72.02 & 11.30 & 50 & 69.82 & 11.79 \\
\hline
\end{tabular}

Tablo 6'da görüldüğü üzere PTÖY'nin uygulandığı deney gruplarındaki öğrencilerin uygulama öncesindeki ortalama puanı 72.58 iken, bu değer uygulama sonrasında 78.68 olmuştur. Mevcut TDÖP uygulanan kontrol gruplarındaki öğrencilerin ortalama puanların sırasıyla 72.02 ve 69.82 'dir. Buna göre deney gruplarındaki öğrencilerin yazılı anlatım becerisi artarken kontrol grubundaki öğrencilerin yazılı anlatım becerisinde düşüş gözlemlenmiştir.

Tablo 7. Yazılı Anlatım Becerisi Dereceli Puanlama anahtarı ön test ve son test puanlarının ANOVA sonuçları

\begin{tabular}{cccccc}
\hline $\begin{array}{c}\text { Varyansın } \\
\text { Kaynağı }\end{array}$ & KT & sd & KO & F & p \\
\hline Gruplar Arası & 23673.375 & 99 & & & .031 \\
Grup (D/K) & 1109.205 & 1 & 1109.205 & 4.817 & \\
Hata & 22564.170 & 98 & 230.247 & & .003 \\
Gruplar İçi & 3002.455 & 100 & & & .000 \\
Ölçüm & 190.125 & 1 & 190.125 & 9.549 & \\
(Ön Test-Son Test) & 861.125 & 1 & 861.125 & 43.249 & \\
Grup* Ölçüm & 1951.205 & 98 & 19.911 & & \\
Hata & 26675.83 & 199 & & & \\
Toplam &
\end{tabular}

Tablo 7'deki veriler incelendiğinde deney ve kontrol gruplarının yazılı anlatım becerisi başarı düzeylerinin deney öncesine göre deney sonrasında anlamlı farklılık gösterdiği, yani farklı işlem gruplarında olma ile tekrarlı ölçümler faktörlerinin yazılı anlatım başarısı üzerindeki ortak etkilerinin anlamlı olduğunu göstermektedir $[F(1,98)=43.249, p<0.05]$. Bu bulgu, PTÖY ve mevcut TDÖP ile uygulama yapılan öğrencilerin yazılı anlatım becerisi başarı puanlarını artırmada farklı etkilere sahip olduğunu göstermektedir. Yazılı anlatım becerisi başarı puanlarında deney öncesine göre artış gösteren PTÖY uygulanan deney gruplarının, mevcut TDÖP uygulanan kontrol gruplarına göre yazılı anlatım becerisi başarı puanlarını artırmada daha etkili olduğu anlaşılmaktadır.

Bulgulara göre PTÖY ve TDÖP uygulanan öğrencilerin yazılı anlatım becerisi başarısı ön test ve son test puanlarından elde edilen toplam puanlarının ortalamaları arasında istatistiksel olarak anlamlı bir farklılık gözlemlenmiştir $[F(1,98)=4.817, p<0.05]$. Ölçüm temel etkisi ile ilgili olarak da, grup ayrımı yapmaksızın araştırmada yer alan öğrencilerin deney öncesinden deney sonrasına yazılı anlatım becerisi başarı puanlarının ortalamaları arasında istatistiksel olarak anlamlı bir farkın olduğu 
söylenebilir $[F(1,98)=9.549, p<0.05]$. Yukarıdaki açıklamalardan da anlaşılacağı üzere deney ve kontrol gruplarındaki öğrencilerin yazılı anlatım becerisi başarı puanları uygulanan yönteme göre farklılık gösterdiği söylenebilir.

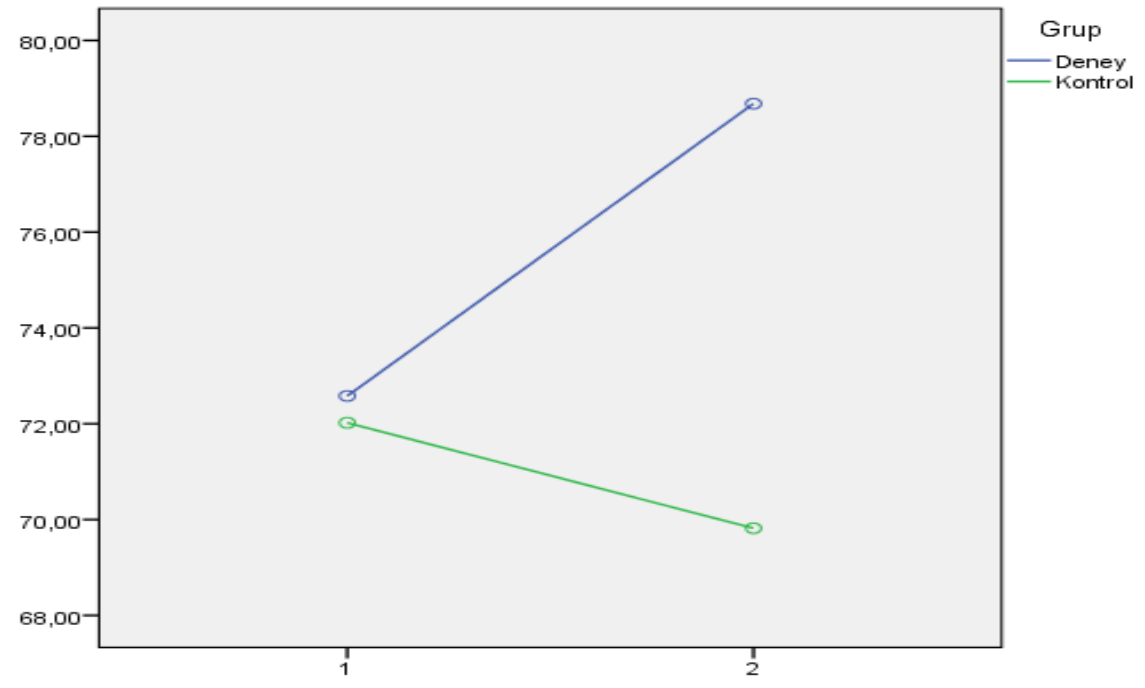

Şekil 1. Deney ve kontrol gruplarındaki öğrencilerin Yazılı Anlatım Becerisi Dereceli Puanlama Anahtarı ön test ve son test puanlarını gösteren grafik.

Deney ve Kontrol Gruplarındaki Öğrencilerin Yazma Kaygısı Ön Test ve Son Test Puanlarına ilişkin Bulgular

Araştırmaya katılan deney ve kontrol gruplarındaki öğrencilerin Yazma Kaygısı Ölçeğinden aldıkları, ön test ve son test puanları arasında istatistiksel olarak anlamlı bir fark olup olmadığına bakılmıştır.

Tablo 8. Deney-1 grubunun yazma kaygısı ön test ve son test puanlarına ilişkin t-testi sonuçları

\begin{tabular}{ccccccc}
\hline Ölçüm (YABDPA) & $\mathrm{N}$ & $\mathrm{X}$ & $\mathrm{S}$ & $\mathrm{sd}$ & $\mathrm{t}$ & $\mathrm{p}$ \\
\hline Ön test & 24 & 58.83 & 9.02 & 23 & 6.81 & .000 \\
Son test & 24 & 39.12 & 9.77 & & & \\
\end{tabular}

Tablo 8'deki Deney-1 grubuna ( $N=24)$ ait analiz sonuçları incelendiğinde yazma kaygısı ön test ve son test puanları arasında istatistiksel olarak anlamlı bir fark [t(23)=-6.81; $p<.05]$ olduğu görülmektedir. Deney-1 grubundaki öğrencilerin uygulama öncesi aldıkları yazma kaygısı puanların ortalaması ( $X=58.83, S=9.02)$ iken, PTÖY uygulamaları sonrasında ( $X=39.12, S=9.77)$ olarak hesaplanmıştır.

Tablo 9. Deney-2 Grubunun yazma kaygısı ön test ve son test puanlarına ilişkin t-testi sonuçları

\begin{tabular}{ccccccc}
\hline Ölçüm (YABDPA) & $\mathrm{N}$ & $\mathrm{X}$ & $\mathrm{S}$ & $\mathrm{sd}$ & $\mathrm{t}$ & $\mathrm{p}$ \\
\hline Ön test & 26 & 57.69 & 10.08 & 25 & 6.62 & .000 \\
Son test & 26 & 40.03 & 10.07 & & & \\
\hline
\end{tabular}


Tablo 9'daki Deney-2 grubuna ( $N=26$ ) ait analiz sonuçları incelendiğinde yazma kaygısı ön test ve son test puanları arasında istatistiksel olarak anlamlı bir fark $[t(25)=6.62 ; p<.05]$ olduğu görülmektedir. Deney-2 grubundaki öğrencilerin uygulama öncesi aldıkları yazma kaygısı puanların ortalaması (X=57.69, S=10.08) iken, PTÖY uygulamaları sonrasında $(X=40.03, S=10.07)$ olarak hesaplanmıştır.

Deney-1 ve Deney-2 gruplarındaki öğrencilerden elde edilen veriler üzerinde yapılan analizler sonucunda ulaşılan bulgulara göre PTÖY uygulamasının öğrencilerin yazma becerisine yönelik kaygılarını azaltmada önemli bir etkiye sahip olduğu söylenebilir.

Tablo 10. Kontrol-1 Grubunun yazma kaygısı ön test ve son test puanlarına ilişkin t-testi sonuçları

\begin{tabular}{ccccccc}
\hline Ölçüm (YABDPA) & $\mathrm{N}$ & $\mathrm{X}$ & $\mathrm{S}$ & $\mathrm{sd}$ & $\mathrm{t}$ & $\mathrm{p}$ \\
\hline Ön test & 24 & 55.41 & 8.71 & 23 & -2.58 & .017 \\
Son test & 24 & 61.04 & 10.11 & & & \\
\end{tabular}

Tablo 10'daki Kontrol-1 grubuna ( $\mathrm{N}=24)$ ait analiz sonuçları incelendiğinde yazma kaygısı ön test ve son test puanları arasında istatistiksel olarak negatif yönde anlamlı bir fark $[\mathrm{t}(23)=-2.58$; p>.05] görülmektedir. Kontrol-1 grubundaki öğrencilerin uygulama öncesi aldıkları yazma kaygısı puanların ortalaması ( $X=55.41, S=8.71)$ iken, mevcut TDÖP uygulamaları sonrasında ( $X=61.04$, $S=10.11$ ) olarak hesaplanmıştır.

Tablo 11. Kontrol-2 Grubunun Yazma Kaygısı Ön Test ve Son Test Puanlarına Ilişkin T-Testi Sonuçları

\begin{tabular}{ccccccc}
\hline Ölçüm (YABDPA) & $\mathrm{N}$ & $\mathrm{X}$ & $\mathrm{S}$ & $\mathrm{sd}$ & $\mathrm{t}$ & $\mathrm{p}$ \\
\hline Ön test & 26 & 55.23 & 6.60 & 25 & -.32 & .751 \\
Son test & 26 & 55.92 & 10.35 & & & \\
\hline
\end{tabular}

Tablo 11 'deki Kontrol-2 grubuna ( $\mathrm{N}=26)$ ait analiz sonuçları incelendiğinde yazma kaygısı ön test ve son test puanları arasında istatistiksel olarak anlamlı bir fark [t(25)=-.32; $>$.05] olmadığı görülmektedir. Kontrol-2 grubundaki öğrencilerin uygulama öncesi aldıkları yazma kaygısı puanların ortalaması ( $X=55.23, S=6.60)$ iken, mevcut TDÖP uygulamaları sonrasında $(X=55.92, S=10.35)$ olarak hesaplanmıştır.

Tablo 12. Yazma Kaygısı Ölçeği ortalama puan ve standart sapma sonuçları

\begin{tabular}{ccccccc}
\hline \multirow{2}{*}{ Grup } & \multicolumn{3}{c}{ Ön Test } & \multicolumn{3}{c}{ Son Test } \\
\cline { 2 - 7 } & $\mathrm{N}$ & $\mathrm{X}$ & $\mathrm{S}$ & $\mathrm{N}$ & $\mathrm{X}$ & $\mathrm{S}$ \\
\hline Deney & 50 & 56.80 & 9.54 & 50 & 39.60 & 9.84 \\
\hline Kontrol & 50 & 55.32 & 7.60 & 50 & 58.38 & 10.45 \\
\hline
\end{tabular}

Tablo 12'de görüldüğü üzere PTÖY'nin uygulandığı deney gruplarındaki öğrencilerin uygulama öncesi yazma kaygısı ortalama puanı 56.80 iken, bu değer uygulama sonrası 39.60 olmuştur. Mevcut TDÖP ile derse devam edilen kontrol gruplarındaki öğrencilerin ortalama puanların sırasıyla 55.32 ve 
58.38'dir. Buna göre deney gruplarındaki öğrencilerin yazma kaygısı azalırken kontrol grubundaki öğrencilerin yazma kaygısının arttığı gözlemlenmiştir.

Tablo 13. Yazma Kaygısı Ölçeği ön test ve son test puanlarının ANOVA sonuçları

\begin{tabular}{cccccc}
\hline $\begin{array}{c}\text { Varyansın } \\
\text { Kaynağı }\end{array}$ & KT & sd & KO & F & P \\
\hline Gruplar Arası & 14201.375 & 99 & & & .000 \\
Grup (D/K) & 3741.125 & 1 & 3741.125 & 35.050 & \\
$\quad$ Hata & 10460.250 & 98 & 106.737 & & .000 \\
Gruplar İçi & 14574.500 & 100 & & & .000 \\
Ölçüm & 2499.245 & 1 & 2499.245 & 35.270 & \\
(Ön Test-Son Test) & 5130.845 & 1 & 5130.845 & 72.407 & \\
Grup* Ölçüm & 6944.410 & 98 & 70.861 & & \\
Hata & 28775.875 & 199 & & & \\
Toplam & & & & & \\
\hline
\end{tabular}

Tablo 13'teki veriler incelendiğinde deney ve kontrol gruplarının yazma kaygısı düzeylerinin deney öncesinden sonrasına anlamlı farklılık gösterdiği, yani farklı işlem gruplarında olma ile tekrarlı ölçümler faktörlerinin yazma kaygısı üzerindeki ortak etkilerinin anlamlı olduğu bulunmuştur $[F(1,98)=72.407, p<0.05]$. Bu bulgu, PTÖY ve mevcut TDÖP ile uygulama yapılan öğrencilerin yazma kaygılarını düşürmede farklı etkilere sahip olduğunu göstermektedir. Yazma kaygısı puanları deney öncesine göre azalan PTÖY uygulanan deney grubunun, mevcut TDÖP uygulanan kontrol grubuna göre yazma kaygısını azaltmada daha etkili olduğu anlaşılmaktadır.

Verilerin analizinden anlaşılacağı üzere PTÖY ve TDÖP uygulanan öğrencilerin yazma kaygısı ön test ve son test puanlarından elde edilen toplam puanlarının ortalamaları arasında istatistiksel olarak anlamlı bir farklılık vardır $[F(1,98)=35.050, p<0.05]$. Ölçüm temel etkisi ile ilgili olarak da grup ayrımı yapmaksızın araştırmada yer alan öğrencilerin deney öncesinden deney sonrasına yazma kaygısı puanlarının ortalamaları arasında istatistiksel olarak anlamlı bir farkın olduğu söylenebilir $[F(1,98)=35.270, p<0.05]$. Yukarıdaki bulgulara bakarak deney ve kontrol grubundaki öğrencilerin yazma kaygısı puanlarının uygulanan yönteme göre farklılık gösterdiği söylenebilir.

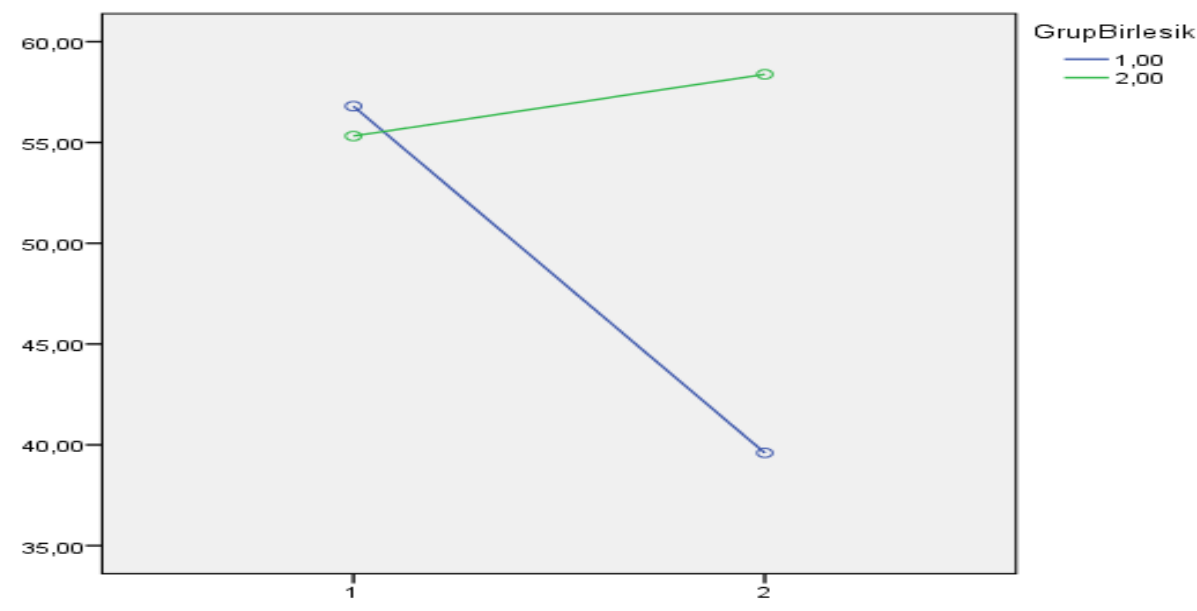

Şekil 2. Deney ve kontrol gruplarındaki öğrencilerin Yazma Kaygısı Ölçeği ön test ve son test puanlarını gösteren grafik. 


\section{Tartışma, Sonuç ve Öneriler}

Araştırma sonuçlarına göre, PTÖY’nin uygulandığı deney gruplarındaki öğrenciler ile mevcut TDÖP'ye göre yazma çalışmaları yapılan gruplarındaki öğrencilerin yazılı anlatım becerisi başarı puanları arasında deney grupları lehine istatistiksel olarak anlamlı bir fark olduğu sonucuna ulaşılmıştır. Buna dayanarak PTÖY'e göre yapılan yazma eğitiminin TDÖP temel alınarak yapılan yazma eğitimine göre öğrencilerin yazma becerilerini geliştirmede daha büyük bir etkiye sahip olduğu söylenebilir. PTÖY ve yazma eğitimi birlikte değerlendirildiğinde bilimsel anlamda yapılan çalışmaların yetersiz olduğu görülmüştür. PTÖY'nin etki düzeyi, daha çok matematik ve fen bilimleri gibi sayısal alanlarda ve sosyal bilgiler, coğrafya gibi sosyal bilimler alanında test edilmiştir. Türkçe eğitiminde ise PTÖY'nin etki düzeyini araştıran çalışmaların çok az olduğu görülmüştür. Araştırmanın birinci alt problemi doğrultusunda ulaşılan sonuçlar, alan yazında ve farklı disiplinlerdeki PTÖY'nin öğrencilerin akademik başarıları üzerindeki etkisini araştıran çalışmalarla benzerlik göstermektedir (Akın, 2016; Aladağ, 2005; Bilgü, 2008; Bozlar, 2017; Demir, 2013; Erdoğan, 2009; Karagül, 2017; Kaya ve Oran, 2015; Memişoğlu, 2008; Varışoğlu ve Sevim, 2014; Yıldııı, 2011; Yılmaz, 2006).

Ayrıca öğrencilerin yazma kaygısını azaltmada PTÖY'nin mevcut TDÖP'ye göre daha etkili olduğu görülmüştür. Literatürde, PTÖY ve yazma kaygısı birlikte değerlendirildiği bir çalışmaya rastlanılmamıştır. Ancak bir yönteme bağlı olarak planlanan eğitim durumlarının yazma kaygısı üzerindeki etkisini araştıran çalışmalar bulunmaktadır (Altuner, 2017; Avcı,2013; Topuzkanamış, 2014).

Araştırmanın elde edilen bulgular sonucunda, Türkçe dersinde uygulanan PTÖY'nin, öğrencilerin yazııı anlatım becerilerini geliştirmede ve yazma kaygılarını azaltmada etkili olduğunu göstermektedir. Bu doğrultuda öğrencilere yazma becerisi kazandırma sürecinde PTÖY tercih edilmesi etkili ve kalıcı öğrenmenin gerçekleşmesini sağlayacaktır. Türkçe öğretim programında var olan yazma etkinlikleri yeterli düzeyde değildir. Yazma etkinlikleri eğitim alanındaki etkisi kanıtlanmış yeni yönelimler dikkate alınarak çeşitlendirilmelidir. Bu yüzden Türkçe öğretim programında araştırmada etkisi kanıtlanmış PTÖY’ye göre hazırlanmış yazma etkinliklerine yer verilmelidir.

\section{Kaynaklar}

Acar, E. N. (2011) Proje tabanlı öğrenmenin fen bilgisi öğretmen adaylarının bilimsel süreç becerilerine ve biyolojiye yönelik tutumlarına etkisi (Yüksek lisans tezi). Çanakkale Onsekiz Mart Üniversitesi Fen Bilimleri Enstitüsü, Çanakkale.

Akın, D. (2016). 6. Sınıf sosyal bilgiler dersinde proje tabanlı öğrenmenin öğrencinin akademik başarısına ve derse karşı tutumuna etkisi (Yüksek lisans tezi). Fırat Üniversitesi Eğitim Bilimleri Enstitüsü, Elazığ.

Aladağ, S. (2005). ilköğretim matematik öğretiminde proje tabanlı öğrenme yaklaşımının öğrencilerin akademik başarısına ve tutumlarına etkisi (Yüksek lisans tezi). Gazi Üniversitesi Eğitim Bilimleri Enstitüsü, Ankara. 
Altuner, ş. G. (2017). 6+1 analitik yazma ve değerlendirme modelinin sınıf öğretmenliği öğrencilerinin yazılı anlatım becerisi ve öz yeterliği ile yazma kaygısına etkisi (Yüksek lisans tezi). Gazi Üniversitesi Eğitim Bilimleri Enstitüsü, Ankara.

Aşılıŏlu, B. ve Özkan, E. (2013). Ortaokul öğrencilerinin yazma kaygılarının bazı değişkenler açısından incelenmesi: Diyarbakır örneği. Turkish Studies, 6(6), 83-111.

Ateş, M., Yıldız, N. ve Ercan, A. N. (2016). Bilim ve sanat merkezlerine devam eden 7. ve 8. sınıf öğrencilerinin yazma kaygılarının incelenmesi. İçinde O. Köksal, E. Hamarta, Ç. Arslan, S. Çiftçi, S. Avşaroğlu, M. Uslu (Ed.), 1st International Academic Research Congress Bildiri Kitabı: (s. 996-1003). Ankara: Pegem Akademi Yayıncılık.

Avcı, A. S. (2013). Yaratıcı yazma etkinliklerinin 8. sınıf öğrencilerinin yazma eğilimleri ve yazma kaygılarına etkisi (Yüksek lisans tezi). Niğde Üniversitesi Eğitim Bilimleri Enstitüsü, Niğde.

Ayvacı, H. Ş. ve Çoruhlu, T. Ş. (2010). Fen ve teknoloji dersi proje tabanlı öğretim uygulamasında ilköğretim öğrencilerinin karşılaştıkları güçlükler. Uludağ Üniversitesi Eğitim Fakültesi Dergisi, 23(1), 43-59.

Bilgü, H. (2008). Ilköğretim sosyal bilgiler dersinde proje tabanlı öğrenme yönteminin öğrenci başarısına etkilerine ilişkin bir araştırma (Yüksek lisans tezi). Dicle Üniversitesi Sosyal Bilimler Enstitüsü, Diyarbakır.

Bloom, L. Z. (1980). The composing process of anxious and non-anxious writers: a naturalistic study. Paper Presented at the annual meeting of the Conferenceon College Composition and Communication. Washington: ERIC Document Reproduction Service No. ED 185559.

Bozlar, B. (2017). Proje tabanlı öğrenmenin 5. sınıf fen bilimleri dersinde öğrencilerin akademik başarı ve bilimsel süreç becerilerine etkisi (Yüksek lisans tezi). Çukurova Üniversitesi Sosyal Bilimler Enstitüsü, Adana.

Büyüköztürk, Ş. (2014). Deneysel desenler öntest-sontest kontrol grubu desen ve veri analizi. Ankara: Pegem Akademi Yayıncılık.

Büyüköztürk, Ş. (2016). Sosyal bilimler için veri analizi el kitabı. Ankara: Pegem Akademi Yayıncılık.

Creswell, J. (2017). Research design qualitative, quantitative, and mixed methods approaches. Thousand Oaks, California: Sage Publication.

Çiftçi, S. (2006). Sosyal bilgiler öğretiminde proje tabanlı öğrenmenin öğrencilerin akademik risk alma düzeylerine, problem çözme becerilerine, erişilerine kalıcılığa ve tutumlarına etkisi (Doktora tezi). Selçuk Üniversitesi Sosyal Bilimler Enstitüsü, Eğitim Bilimleri Anabilim Dalı, Konya.

Demir, T. (2013). Türkçe Öğretimi dersinde proje tabanlı öğrenme yaklaşımı. Ana Dili Eğitimi Dergisi, 1(1), 5376.

Demiral, Ü. (2015). Proje tabanlı öğrenme yaklaşımı. İçinde G. Ekici (Ed.) Etkinlik örnekleriyle güncel öğrenmeöğretme yaklaşımları-Il (s. 459-500). Ankara: Pegem Akademi Yayıncılık.

Erdoğan, N. F. (2009). Ilköğretim sosyal bilgiler öğretiminde, proje tabanlı öğrenmenin ders başarısına ve sınıf atmosferine etkisi (Yüksek lisans tezi). Dokuz Eylül Üniversitesi Eğitim Bilimleri Enstitüsü, İzmir.

İşeri, K. ve Ünal, E. (2012). Türkçe öğretmen adaylarının yazma kaygı durumlarının çeşitli değişkenler açısından incelenmesi. Mersin Üniversitesi Eğitim Fakültesi Dergisi, 8(2), 67-76.

Karagül, S. (2017). Türkçe öğretiminde proje tabanlı öğrenme yöntemiyle desteklenen basamaklı öğretim programının öğrencilerin okuma ve yazma becerilerine etkisi (Doktora tezi). Ankara Üniversitesi Eğitim Bilimleri Enstitüsü, Ankara.

Karakaya, İ. ve Ülper, H. (2011). Yazma kaygısı ölçeğinin geliştirilmesi ve yazma kaygısının çeşitli değişkenlere göre incelenmesi. Kuram ve Uygulamada Ĕgitim Bilimleri, 11(2), 691-707.

Karakuş Tayşi, E. ve Taşkın, Y. (2018). Ortaokul öğrencileri için yazma kaygısı ölçeğinin geliştirilmesi: Geçerlik ve güvenirlik çalışması. Uluslararası Türkçe Edebiyat Kültür Eğitim Dergisi (TEKE), 7(2), 1172-1189. 
Kaya, M. ve Oran, G. (2015). Proje tabanlı öğrenme yaklaşımı ve Türkçe öğretimine yönelik bir uygulama. Türkçe Konuşanların Akademik Dergisi (TURKOPHON), 2(1), 17-25.

Katrancı, M. (2015). Bireysel ve grupla yazma uygulamalarının yazma kaygısı ve yazılı anlatım öz yeterlik algıSı üzerine etkisi. Route Educational and Social Science Journal, 2(2), 40-55.

Korkmaz, H. ve Kaptan, F. (2001). Fen eğitiminde proje tabanlı öğrenme yaklaşımı. Hacettepe Üniversitesi Eğitim Fakültesi Dergisi, 20, 193-200.

Maltepe, S. (2007). Yaratıcı yazma yaklaşımı açısından Türkçe derslerinde oluşturulan yazılı anlatım ürünlerinin değerlendirilmesi. Eurasian Journal of Educational Research, 26, 143-154.

Memişoğlu, H. (2008). Sosyal bilgiler dersi öğretiminde proje tabanlı öğrenme yaklaşımı (Doktora tezi). Gazi Üniversitesi Eğitim Bilimleri Enstitüsü, Ankara.

Özdemir, B. (2014). Analitik yazma ve değerlendirme modelinin Türkçe öğretmeni adaylarının yazma becerilerine ve yazma tutumlarına etkisi (Doktora tezi). Gazi Üniversitesi Eğitim Bilimleri Enstitüsü, Ankara.

Özer, A. (2007). Normallik testlerinin karşılaştırılması (Yüksek lisans tezi). Ankara Üniversitesi Fen Bilimleri Enstitüsü, Ankara.

Punch, K.F. (2014). Introduction to research methods in education. London: Sage Publications.

Saracaloğlu, A. S., Özyılmaz Akmaca G. ve Yeşildere S. (2006). İlköğretimde proje tabanlı öğrenmenin yeri. Türk Eğitim Bilimleri Dergisi, Gazi Üniversitesi 3(4), 1-21.

Topuzkanamış, E. (2014). Yazma stratejileri öğretiminin Türkçe öğretmenliği birinci sınıf öğrencilerinin yazılı anlatım başarısı ve yazma kaygısına etkisi (Doktora tezi). Gazi Üniversitesi Eğitim Bilimleri Enstitüsü, Ankara.

Varışoğlu, B. ve Sevim, O. (2014). Proje tabanlı iş birlikli öğrenmenin öğrencilerin Türkçe dersindeki ekler konusunu öğrenmelerine etkisi. Uluslararası Sosyal araştırmalar Dergisi (The Journal of International Social Research), 7(32), 540-551.

Yıldırım, H. (2011). Probleme dayalı öğrenme ve proje tabanlı öğrenme yöntemlerinin ilköğretim öğrencilerinin başarılarına ve tutumlarına etkisi (Yüksek lisans tezi). Selçuk Üniversitesi Eğitim Bilimleri Enstitüsü, Konya.

Yılmaz, O. (2006). Ilköğretim 7.sınıf sosyal bilgiler dersinde proje tabanlı öğrenmenin öğrenenlerin akademik başarıları, yaratıcılıkları ve tutumlarına etkisi (Yüksek lisans tezi). Zonguldak Karaelmas Üniversitesi Sosyal Bilimler Enstitüsü, Zonguldak.

\section{Extended Abstract}

Introduction

Writing connects the past and future of an individual. Moreover, writing enables individual to use cognitive, affective, and psychomotor fields, effectively. As one of the four main language skills, writing is considered as the last chain. Writing is a way in which an individual expresses her/his emotions, thoughts, dreams, observations, plans, experiences, and practices via symbols; in other words, it is one of the ways of communicating with others and expressing herself/himself (ArıCı and Ungan, 2015; Göçer, 2016; Sever, 2015). Since the writing skill is hard to acquire as a separate component through theoretical and technical information, it needs to be internalized and put into practice. Writing skill is a challenging skill which requires interest and motivation. While teaching writing skills, these difficulties should be eliminated (Ateş, Yıldız and Ercan, 2016). Unless it is excessive, anxiety helps individuals select, rank, and organize thoughts and put them on paper. So that an individual can express herself/himself better (Aşılıoğlu and Özkan, 2013). Writing anxiety causes individuals who are exposed to writing be afraid, feel shy, and postpone or abandon writing tasks. One of the modern learning approaches which makes learning more functional and defends learner-centeredness is Project Based Learning Approach (PBLA). PBLA is a learning approach which takes learner in its centre (Ayvacl and Çoruhlu, 2010; Demiral, 2015). With the help of PBLA, it will be easy to increase academic success of students in writing skills, to eliminate the detected writing problems, and ease their anxiety about writing through writing projects in which students feel free. For these reasons, the effects of PBLA on the development 
of writing skills and on the elimination of writing anxiety in middle school students are examined in this research.

Method

In this research quasi-experimental design with pre-test post-test control groups which includes activities and projects designed to detect causality relationship between variables was used. Occurring in a natural way, experimental groups are defined although they are not set in accordance with the aim of the research. That's why, supervision of the experiment by the researcher is difficult. However, the researcher finds an opportunity to detect to some extent while measuring the effect level of independent variable on output variables (Büyüköztürk, 2014; Creswell, 2017; Punch, 2014). The research was carried out with 100 students who study in the $7^{\text {th }}$ grade in 2016-2017 education year at Cengizhan Middle School in Kağıthane, İstanbul. The $7^{\text {th }}$ graders were preferred since they were appropriate in terms of readiness, and academic anxiety. In the study, "Personal Information Form," "Writing Anxiety Scale," "Written Expression Skills Graduate Grading Key," and "Project Evaluation Scale" were used as the data collection tools. In the process of the research, a 10-week curriculum was designed in accordance with principles of PBLA to achieve target acquisitions. SPSS 21.0 programme was used in the statistical analysis of the data.

\section{Result and Discussion}

This study aims to determine the effects of PBLA on the development of writing skills of middle school students and their anxiety about writing. In this regard, the first sub problem of the research is expressed as follows. "Is there a significant difference between written expression skills success points of students who were in experimental groups in which PBLA was applied and in control groups taught in accordance with TLC?" According to the results, it was concluded that there had been a statistically significant difference between written expression skill success points of students in experimental groups in which PBLA was applied and in control groups being taught in accordance with TLC on the experimental groups' favour. As it was observed that there had been a statistically significant increase in the pre-test and post-test written expression skills success points of students in experimental groups in which writing activities were designed based on PBL, it was proved to be the opposite in the control groups. These findings revealed that writing education given in accordance with PBLA had a positive effect on the development of writing skills of students compared to the writing education presented in accordance with TLC. Additionally, according to the intra-group and inter-group analyses of students, it was observed that experimental groups has been more effective in the elimination of anxieties compared to control groups. Findings figured out in relation to sub problems of the research revealed that PBLA applied to Turkish lesson has been effective in the improvement of written expression skills and in elimination of their writing anxiety. 